\title{
Imaging the East European Craton margin in northern Poland using extended correlation processing of regional seismic reflection profiles
}

\author{
Miłosz Mężyk ${ }^{1}$, Michał Malinowski ${ }^{1}$, and Stanisław Mazur ${ }^{2}$ \\ ${ }^{1}$ Institute of Geophysics Polish Academy of Sciences, Warsaw, 01-452, Poland \\ ${ }^{2}$ Institute of Geological Sciences Polish Academy of Sciences, 00-818, Warsaw, Poland \\ Correspondence: Miłosz Mężyk (mmezyk@igf.edu.pl)
}

Received: 4 February 2019 - Discussion started: 21 February 2019

Revised: 9 April 2019 - Accepted: 29 April 2019 - Published: 21 May 2019

\begin{abstract}
In NE Poland, Eastern European Craton (EEC) crust of Fennoscandian affinity is concealed under a Phanerozoic platform cover and penetrated by sparse, deep research wells. Most of the inferences regarding its structure rely on geophysical data. Until recently, this area was covered only by the wide-angle reflection and refraction (WARR) profiles, which show a relatively simple crustal structure with a typical three-layer cratonic crust. ION Geophysical PolandSPAN $^{\mathrm{TM}}$ regional seismic programme data, acquired over the marginal part of the EEC in Poland, offered a unique opportunity to derive a detailed image of the deeper crust. Here, we apply extended correlation processing to a subset $(\sim 950 \mathrm{~km})$ of the PolandSPAN ${ }^{\mathrm{TM}}$ dataset located in NE Poland, which enabled us to extend the nominal record length of the acquired data from 12 to $22 \mathrm{~s} \mathrm{(} \sim 60 \mathrm{~km}$ of depth). Our new processing revealed reflectivity patterns, which we primarily associate with the Paleoproterozoic crust formed during the Svekofennian (Svekobaltic) orogeny, that are similar to those observed along the BABEL and FIRE profiles in the Baltic Sea and Finland, respectively. We propose a mid- to lower-crustal, orogeny-normal lateral flow model to explain the occurrence of two sets of structures that can be collectively interpreted as kilometre-scale $\mathrm{S}-\mathrm{C}^{\prime}$ shear zones. The structures define a penetrative deformation fabric invoking ductile extension of hot orogenic crust in a convergent setting. Localized reactivation of these structures provided conduits for subsequent emplacement of gabbroic magma that produced a Mesoproterozoic anorthositemangerite-charnockite-granite (AMCG) suite in NE Poland. Delamination of thickened orogenic lithosphere may have accounted for magmatic underplating and fractionation into
\end{abstract}

the AMCG plutons. We also found sub-Moho dipping mantle reflectivity, which we tentatively explain as a signature of the crustal accretion during the Svekofennian orogeny. Later tectonic phases (e.g. Ediacaran rifting, Caledonian orogeny) did not leave a clear signature in the deeper crust; however, some of the subhorizontal reflectors below the basement, observed in the vicinity of the AMCG Mazury complex, can be alternatively linked with lower Carboniferous magmatism.

\section{Introduction}

The Precambrian East European Craton (EEC) is composed of three major crustal blocks: Fennoscandia, Sarmatia, and Volgo-Uralia (Gorbatschev and Bogdanova, 1993). Fennoscandia was formed in the Paleoproterozoic during the Svecofennian orogeny (see e.g. Lahtinen et al., 2009). Its crust was imaged by several deep reflection profiles, mostly offshore (Baltic Sea) (Abramovitz et al., 1997; BABEL Working Group, 1993; Korja and Heikkinen, 2005; Meissner and Krawczyk, 1999), with a notable exception of the FIRE project in onshore Finland (Kukkonen and Lahtinen, 2006; Torvela et al., 2013). In NE Poland, the Fennoscandian crust is concealed under a Phanerozoic platform cover and is penetrated by sparse, deep research wells. See Krzemińska et al. (2017) for a recent summary. Therefore, most of the inferences regarding its structure rely on geophysical data. Until recently, this area was covered only by wide-angle reflection and refraction (WARR) profiles from the POLONAISE'97 project (P2, P3, P4, P5 profile; Czuba et al., 2002; 
Grad et al., 2003; Janik et al., 2002; Środa et al., 1999) and legacy transects (LT-7 profile; Guterch et al., 1994). They portray relatively simple crustal structure with typical cratonic three-layer crust (Grad et al., 2010). Experimental deep reflection seismic profile GB1 shot between 1987 and 1988 revealed complex reflectivity patterns in the deeper crust of the Pomerania region (Dziewinska and Tarkowski, 2016), but the low quality of the seismic data precludes any definite interpretation. Recently this area was covered by the deep reflection seismic profiles of the ION Geophysical PolandSPAN $^{\mathrm{TM}}$ project. In 2012, 10 PolandSPAN ${ }^{\mathrm{TM}}$ profiles (with a total length of $2200 \mathrm{~km}$ ) were acquired in Poland over the marginal part of the EEC, east of the Teisseyre-Tornquist Zone (TTZ). This large regional seismic programme aimed to provide a better understanding of the sedimentary history, tectonic architecture, and basement structure of the lower Paleozoic shale basins (Krzywiec et al., 2013). Because of their regional character and unprecedented imaging quality, PolandSPAN ${ }^{\mathrm{TM}}$ data have already revolutionized several aspects of the regional geology of Poland. These seismic profiles have been used as constraints for potential field modelling that led to a new interpretation of the TTZ (Mazur et al., 2015, 2016b) and Polish Caledonides (Mazur et al., 2016a). In SE Poland, interpretation of the PolandSPAN ${ }^{\mathrm{TM}}$ profiles proved that the Variscan deformation extends much further to the east than previously assumed (Krzywiec et al., 2017a, b). Malinowski (2016) showed that these data can be effectively used to study deep crustal structure by employing the extended correlation method of Okaya and Jarchow (1989), showing, e.g. presence of the reflective lower crust underlying the EEC in SE Poland, previously imaged by the POLCRUST-01 profile (Malinowski et al., 2013, 2015).

Here, we apply extended correlation processing to a subset of the PolandSPAN ${ }^{\mathrm{TM}}$ data located in NE Poland: three $\operatorname{dip}(5400,5500,5600)$ and two strike profiles $(1100,1200)$ with a total length of $\sim 950 \mathrm{~km}$. Since Precambrian crust in Poland is concealed beneath a Phanerozoic platform cover, previous inferences were based mostly on the sparse, deep research wells available (Krzemińska et al., 2017), but with these new seismic reflection data it is now possible to shed light on the characteristics of the deeper EEC crust in NE Poland. The key questions we would like to address using these new data are as follows: (i) is the image of the Svecofennian orogen in NE Poland similar to that observed further north in Fennoscandia, e.g. in the Bothnian Bay (Korja and Heikkinen, 2005) and onshore Finland (Torvela et al., 2013)? (ii) Do we see a crustal expression of the Mesoproterozoic magmatism? (iii) Are the later tectonic events (like Ediacaran rifting of Rodinia or Caledonian tectonics) also recognizable in the crustal reflectivity patterns? We start with the geological background, then we summarize the processing steps focused on enhancing deeper reflectivity, and finally we present the new results and integrate them with the existing geological observations to provide some preliminary interpretation of the crustal structure in NE Poland.

\section{Geological background}

The study area is located in NE Poland at the western margin of the EEC and Fennoscandia (Fig. 1). Its core was formed during the Paleoproterozoic Svecofennian orogeny, which involved accretion of several microcontinents and island arcs (Lahtinen et al., 2009). Lahtinen et al. (2009) distinguish a separate phase of the Svecofennian accretion called the Svekobaltic orogeny $(1.83-1.8 \mathrm{Ga})$. In the cross-Baltic correlations by Bogdanova et al. (2015), the area of NE Poland belongs to a microcontinent called Amberland (Fig. 1) with a $1.83-1.84 \mathrm{Ga}$ accretion age. Subsequently, the Paleoproterozoic crust was influenced by Mesoproterozoic (1.54-1.45 Ga) anorogenic magmatic activity, producing anorthosite-mangerite-charnockite-granite (AMCG) complexes in a $\sim 600 \mathrm{~km}$ long zone stretching from Belarus, through Lithuania, NE Poland, and the southern Baltic Sea (Dörr et al., 2002; Skridlaite et al., 2003; Krzemińska et al., 2017). No signature of the Svekonorwegian orogeny $(1.14-0.9 \mathrm{Ga})$ affecting the western rim of Fennoscandia (Bogdanova et al., 2008) was recognized in our study area. Ediacaran rifting during Rodinia break-up (e.g. Johansson, 2009) eventually led to the formation of a passive margin of Baltica in the early Cambrian. No magmatic activity related to this stage of the EEC margin development has been recognized in NE Poland. The western part of the study area was also affected by Caledonian tectonics. An extensive flexural basin, named the Baltic Basin, was developed in the Silurian in front of the Caledonian orogen. The basin focused deposition of a fine-grained siliciclastic succession up to $4000 \mathrm{~m}$ thick that gradually thins out to the east and constitutes most of the Phanerozoic platform cover of the EEC. The western part of the Baltic Basin was intensely folded to form the Pomeranian Caledonides. The concept of Pomeranian Caledonides was initially based on the analysis of the deep research wells (Dadlez et al., 1994), but it was recently confirmed by PolandSPAN ${ }^{\mathrm{TM}}$ line 5600 , which was interpreted to image the frontal thrust of the deformed upper Ordovician and Silurian sedimentary succession with the undeformed lower Paleozoic sediments of the Baltic Basin (Mazur et al., 2016a). The youngest magmatic episode affecting the EEC crust included lower Carboniferous (354-338 Ma) alkali magmatism with several syenite intrusions (Fig. 2; e.g. Krzemińska et al., 2017), coeval with the dolerite sills intruding Silurian sediments offshore of Lithuania (Motuza et al., 2015). According to the revised lithostratigraphy (Krzemińska et al., 2017), crystalline basement units of the study area can be further subdivided into the Dobrzyń domain (DD), Mazury complex (MC), and Pomerania-Blekinge Belt (PBB) (Fig. 2). The DD (1.82-1.76 Ga) basement comprises synorogenic gran- 


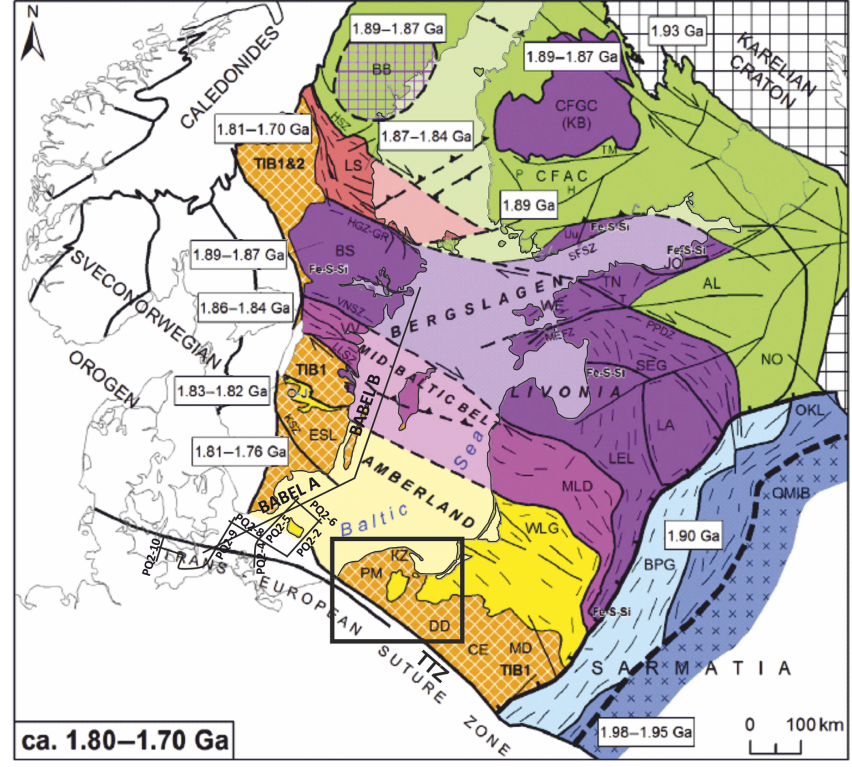

Figure 1. Major Paleoproterozoic tectonic domains of Fennoscandia across the Baltic Sea area. The black rectangle shows the study area. The location of the BABEL A-B (BABEL Working Group, 1993) and DEKORP-PQ (Meissner and Krawczyk, 1999) deep reflection profiles is also marked. The known extent of the domain affected by the Svecofennian orogeny (coloured terranes) is bounded by the Teisseyre-Tornquist Zone (TTZ) in the SW and the BelarusPodlasie granulite belt (BPG) in the SE. Modified from Bogdanova et al. (2015).

ites and supracrustal paragneisses. The PBB (1.79-1.74 Ga) basement includes synorogenic granodiorites, quartz monzonites, and granites, whereas the MC $(1.54-1.49 \mathrm{Ga})$ is composed of the anorogenic AMCG association: quartz monzonites, charnockitoids, diorites, and monzogabbros. Their occurrences are clearly visible in the magnetic anomaly map as magnetic highs (Fig. 3).

\section{Data and methods}

\subsection{Acquisition}

The PolandSPAN ${ }^{\mathrm{TM}}$ project employed acquisition parameters that were primarily optimized to provide a continuous image of the lower Paleozoic shale basins. Data were acquired with a $25 \mathrm{~m}$ receiver-shot spacing and 960-channel symmetric spread (max. offset of $12 \mathrm{~km}$ ), providing a nominal fold of 480 with a common depth point (CDP) spacing of $12.5 \mathrm{~m}$. The source array consisted of four INOVA AHV-IV Commander $(62000 \mathrm{lb}$. peak force) Vibroseis trucks. A custom broadband $(2-150 \mathrm{~Hz}) 16 \mathrm{~s}$ long $\left(\tau_{\text {sweep }}\right)$ upsweep was used. In the field, uncorrelated data ( $28 \mathrm{~s}$ of listen time, $\left.\tau_{\text {record }}\right)$ were recorded with auxiliary data containing measurements of weighted-sum ground force $\left(F_{\mathrm{WS}}\right)$, an estimate of the vi-

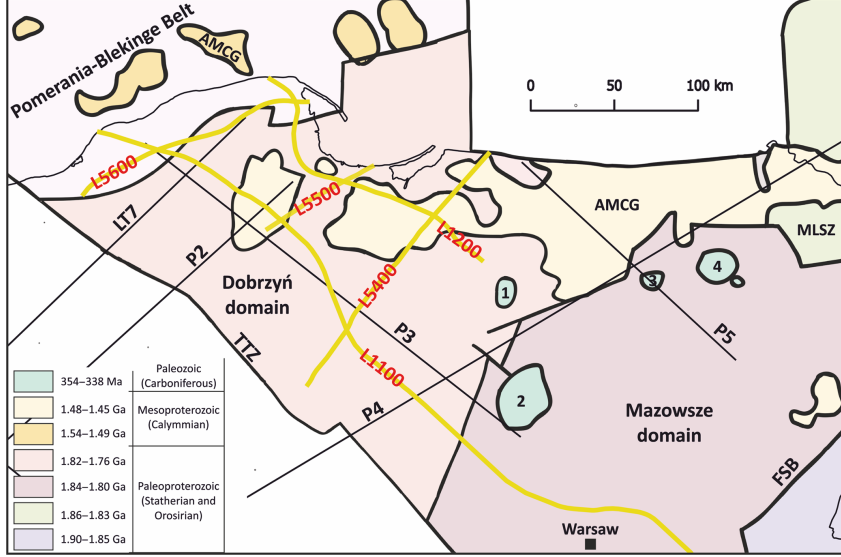

Figure 2. Location of the PolandSPAN ${ }^{\mathrm{TM}}$ seismic profiles (yellow lines) on the background of a simplified geological map of the East European Craton crystalline basement units (after Krzemińska et al., 2017). TTZ - Teisseyre-Tornquist Zone, FSB - FennoscandiaSarmatia boundary, AMCG - anorthosite-mangerite-charnockitegranite complexes, MLSZ - Mid-Lithuanian Suture Zone, Paleozoic massifs: 1 - Olsztynek, 2 - Mława, 3 - Pisz, 4 - Ełk. Locations of WARR profiles LT7 (Guterch et al., 1994), POLONAISE'97 P2 (Janik et al., 2002), P3 (Środa et al., 1999), P4 (Grad et al., 2003), and P5 (Czuba et al., 2002) are marked as thin black lines.

brator ground force $\left(F_{\mathrm{g}}\right)$ (Ziolkowski, 2010) for each vibrator in the array.

\subsection{Processing}

ION Geophysical original time and depth imaging were focused on the sedimentary cover structure with a processing sequence optimized to preserve the original sweep bandwidth in the sedimentary cover. Reflection tomography was used to build the velocity model for pre-stack depth migration (PSDM) in the sedimentary section, while below the basement, WARR-derived velocities were used. The nominal record length of $12 \mathrm{~s}$ enabled imaging down to the lower crust on average. Malinowski and Brettwood (2013) and Malinowski (2016) provided a proof of concept: by using the extended correlation method of Okaya and Jarchow (1989), PolandSPAN $^{\mathrm{TM}}$ data could be extended to greater times $(\sim 20$ s). Malinowski (2016) also demonstrated that despite relatively short (16s vs. 45-60 s long sweeps used during the POLCRUST-01 acquisition; Malinowski et al., 2013) and broadband $(2-150 \mathrm{~Hz}$ as opposed to $6-64 \mathrm{~Hz})$ upsweep, reliable imaging of the deeper structures (including the Moho) can be obtained.

Therefore, the first step in our reprocessing was the application of a self-truncating extended correlation, which increased the nominal record length $t_{\text {profile }}$ from 12 to $22 \mathrm{~s}$. "Self-truncating" means that the reference signal we correlate with the recorded data was truncated during the correlation process, preserving the full bandwidth for the original 


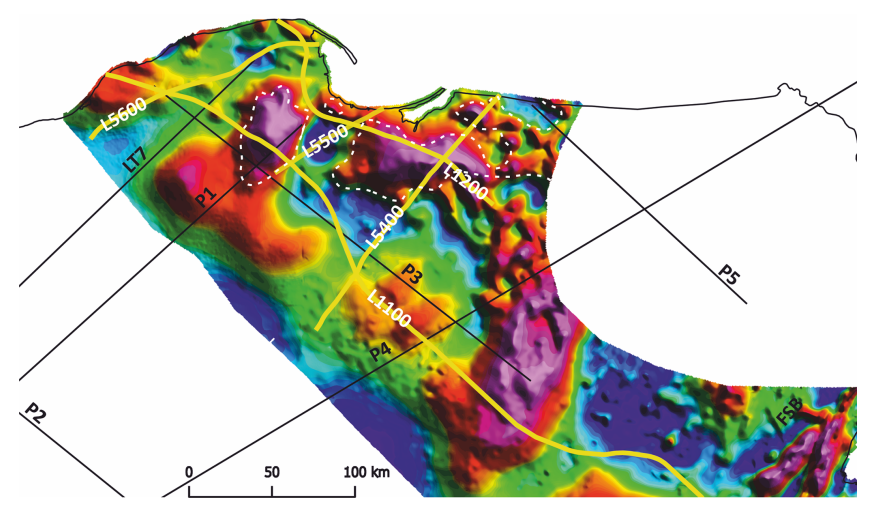

Figure 3. Location of the PolandSPAN ${ }^{\mathrm{TM}}$ seismic profiles on the background of a total magnetic field anomaly map of NE Poland (reduced to pole) (data compilation of Stanisław Mazur). The location of the AMCG complexes from Fig. 2 is also indicated by a white dashed line.

record length but losing bandwidth at later times. Given the acquisition parameters of the PolandSPAN ${ }^{\mathrm{TM}}$ survey, a maximum frequency $f_{\max }$ was limited to $57.5 \mathrm{~Hz}$ at $22 \mathrm{~s}$ of extended time. It can be derived using the following formulas of Okaya and Jarchow (1989), assuming linear upsweep.

$$
\begin{aligned}
& \tau_{\text {record }}=\tau_{\text {sweep }}+\tau_{\text {listen }} \\
& t_{\text {profile }}=\tau_{\text {record }}-\tau_{\text {sweep }} \\
& f_{\text {max }}(t)=f_{1} \quad 0 \leq t \leq t_{\text {profile }} \\
& f_{\text {max }}(t)=f_{1}-\frac{f_{1}-f_{0}}{\tau_{\text {sweep }}}\left(t-t_{\text {profile }}\right) \quad t_{\text {profile }} \leq t \leq \tau_{\text {record }}
\end{aligned}
$$

In the case of Vibroseis acquisition, data are usually correlated with the theoretical (pilot) sweep. As mentioned above, for the PolandSPAN ${ }^{\mathrm{TM}}$ data, we have the ground-force estimates for every Vibroseis point (VP) location. When Malinowski (2016) compared stacks of data correlated with both pilot sweep and ground-force estimates averaged over all VPs, he found that substituting one for another in the correlation process did not contribute to a significant change in the final stack quality. However, in this study, we prefer to correlate raw data with a ground force averaged for every VP, since spatially varying ground-force estimates (which should compensate for variable baseplate coupling) are more realistic than a simple theoretical signal.

After the re-correlation process, we started the basic processing sequence, which was focused on the middle to lower crust and the upper mantle depths. For quality control purposes, several stacked sections for each line were produced at various stages and thoroughly assessed in terms of how processing methods and their parameters affected the seismic signal. Following this routine, the most effective processing sequence and parameter configuration were determined. The processing is summarized in Table 1.

We put a lot of effort into estimating the refraction static corrections because we decided not to use the contractor's
Table 1. Data processing scheme.

\begin{tabular}{ll}
\hline 1. & Read uncorrelated SEG-D records \\
2. & Extended correlation with ground force \\
3. & Resample to $4 \mathrm{~ms}$ \\
4. & Geometry set-up and quality control \\
5. & Trace editing \\
6. & Surface-consistent amplitude scaling \\
& (receivers and shots) \\
7. & Spherical divergence correction \\
8. & Refraction statics (final datum $400 \mathrm{~m})$ \\
9. & Minimum phase conversion \\
10. & Surface-consistent deconvolution \\
11. & Predictive deconvolution \\
12. & Residual statics \\
13. & FX deconvolution \\
14. & Bandpass filtering (2-6-38-48 Hz) \\
15. & Residual statics \\
16. & AGC \\
17. & Kirchhoff DMO \\
18. & CDP stack \\
19. & Linear coherency filtering \\
20. & Post-stack Stolt migration \\
21. & Bandpass filtering (8-10-20-30 Hz) \\
22. & Trace equalization \\
23. & Time-depth conversion \\
&
\end{tabular}

solution. Towards this end, we employed an in-house neuralnetwork-based algorithm (Mezyk and Malinowski, 2018) for picking first breaks. Both elevation statics and refraction statics were applied here using a datum elevation of $400 \mathrm{~m}$ and a replacement velocity of $2250 \mathrm{~m} \mathrm{~s}^{-1}$ (the same as for original processing). Initially, we processed the data with a relative amplitude preservation; however, it turned out that qualitatively better results for the deeper crust were obtained with a pre-stack AGC scaling (5 s window). We used ION Geophysical pre-stack time migration (PSTM) root mean square (RMS) velocity models for the NMO-DMO corrections. Mild coherency filtering was applied pre-stack (only FX deconvolution). Dip moveout corrections (DMO) appeared to be an essential step. We used a Kirchhoff-integral-based DMO algorithm on the common offset planes. It brought improvements into the sections by strengthening the continuity of reflectors and correcting for conflicting dips. In general, migrating the DMO-corrected stacked sections provided a clearer image with increased reflection consistency in both the vertical and horizontal direction. After the DMO stack, signal coherency was substantially increased with a poststack linear dip filtering. Careful tuning of the parameters was required not to create artificial events. Dip-filtered stacks were subsequently migrated. We tested the line-segment migration code (Calvert, 2004), but because of the generally noisier appearance of such migrated sections, we prefer to use simple $F-K$ (Stolt) migration. Finally, depth conversion was carried out. Velocity models for depth conversion 
were merged from the PSDM velocity models provided by ION Geophysical for the section above the basement and the compilation of the crustal velocity model for Poland derived from WARR data (Grad et al., 2016) for the deeper section below the basement.

\section{Results}

The final migrated depth-converted sections presented in Figs. 4 and 5 formed the basis for defining the structural relationships and reflector orientations. The reprocessed profiles illustrate a variety of crustal reflectivity patterns, reflection Moho, and dipping mantle reflections. In order to facilitate interpretation, the amplitude envelope is computed from the final stacks, smoothed, and displayed as a colour background.

Signal-penetration depth was estimated from the amplitude decay curves (Fig. 6), extracted from the final stacked sections, following Barnes (1994). In order to detect amplitude variability along the profiles, each seismic section is divided into two parts within which the corresponding decay curves are calculated. Amplitude decay curves represent the root mean square (RMS) amplitude generated using a $200 \mathrm{~ms}$ long sliding window that yields curves not too smooth or overly spiky.

Analysis of the reprocessed seismic sections shows that, in general, the reflectivity of the crust is not stationary, and its intensity may vary from high (e.g. L1200 at CDP 30006000) to low (e.g. L5400 at CDP 3500-5000) or even be characterized as acoustically transparent (e.g. L5400 at CDP 1500-3500), indicating a gradual transition from crustal to mantle rocks. Observed intracrustal reflections are mostly discontinuous but not chaotic. They form patterns that can be either subhorizontal (e.g. L5400 at $\sim 8 \mathrm{~km}$ and CDP 500010000 ) or gently dipping at an angle not exceeding 20 degrees (e.g. L5600 at 12-22 km and CDP 7000-11 000). The presence of abnormally strong reflectivity zones can also be marked, especially in a depth range of 20 to $36 \mathrm{~km}$ in the area where lines 5400 and 1200 cross (Figs. 4-5). The transition between the lower crust and the uppermost mantle is often trackable (as a change in a generally reflective crust vs. transparent mantle or as a band of stronger reflectivity at the expected Moho depth), undulating slightly between 36 and $42 \mathrm{~km}$, yet in some parts of the stacked sections, the signal penetration is insufficient to image Moho. It is clearly visible in the case of line 5400, for which the amplitude decay curves calculated for the SW and NE part are substantially different in terms of reflectivity strength. Without averaging over thousands of CDPs, the decay amplitudes would flatten out at $20 \mathrm{~km}$ for the transparent CDP interval between 1500 and 3500. In contrast to the poorly defined Moho in this part of line 5400, a very sharp boundary is observed along line 5600 and 1200 , in a CDP range of 3000-6000 and 1-2500, respectively. The stacked section for line 5400 shows evidence of a small symmetrical Moho uplift that emerges around CDP 6000 and extends for $\sim 90 \mathrm{~km}$ in the NE direction. The Moho can also be inferred from the amplitude decay curves (which we present in the time domain as originally calculated) as a change in decay rate at $13 \pm 1 \mathrm{~s}$ of two-way time whereby the curves do not decay further. This time corresponds roughly to a depth of $40 \mathrm{~km}$, a level characterized by a sudden reflectivity drop on the seismic sections presented in the depth domain. Some reflections might continue into the upper mantle, such as the events visible on line 5600 and 1200 between CDP 1 and 2000 and between 13500 and 14500 , respectively. Some of the weaker sub-Moho reflectivity might be related to migration artefacts or other processing footprints; however, the stronger ones (e.g. the one at line 5600) seem to be real.

\section{Discussion and preliminary interpretation}

The reprocessed PolandSPAN ${ }^{\mathrm{TM}}$ profiles from NE Poland show a much more complex architecture of the EEC crust compared with the WARR data (Grad et al., 2010), which is a result of the different methodologies employed. However, as discussed below, it is not only an issue of more complex reflectivity observed in the reflection profiles but also a redefinition of the middle-lower crust and Moho depths.

The thickness of the Phanerozoic platform cover varies from $\sim 7-8 \mathrm{~km}$ in the SW to less than $2 \mathrm{~km}$ in the NE (Figs. 7-9). With few exceptions (e.g. SW part of line 5400; Fig. 8), reflection Moho is relatively well defined as the base of bands of intermittent reflections dividing reflective crust from the generally more transparent upper mantle. In the following comparisons, we use the compilation of WARR data by Majdański (2012), including the top lower crust and Moho horizons. The depth to WARR Moho varies smoothly along the interpreted PolandSPAN ${ }^{\mathrm{TM}}$ profiles between 38 and $43 \mathrm{~km}$ with a typical value around $40 \mathrm{~km}$, being close to the global average of the "normal" continental crust (Christensen and Mooney, 1995). The agreement between such defined WARR Moho and the assumed crust-mantle boundary interpreted in the reflection data is good, with some notable exceptions. Reflection Moho along line 1200 is $\sim 2-3 \mathrm{~km}$ shallower than the WARR Moho (Fig. 7). Reflection Moho in the NE part of line 5600 is up to $4 \mathrm{~km}$ shallower. Reflection Moho along line 5500 is $\sim 2 \mathrm{~km}$ shallower. In the case of line 5400 , a Moho uplift $(\sim 2-3 \mathrm{~km})$ is observed. See the discussion on the AMCG complex below. However, considering the fact that the velocities in the sedimentary cover are poorly resolved in WARR models and we used reflection-derived velocities at shallower depths, those changes can be attributed to the differences between those two methods. The depth to lower crust was inferred using WARR data and the change in the reflectivity patterns observed between the mid- to lowercrustal depths. The lower crust generally has a much-reduced thickness compared with the WARR model. We can note 

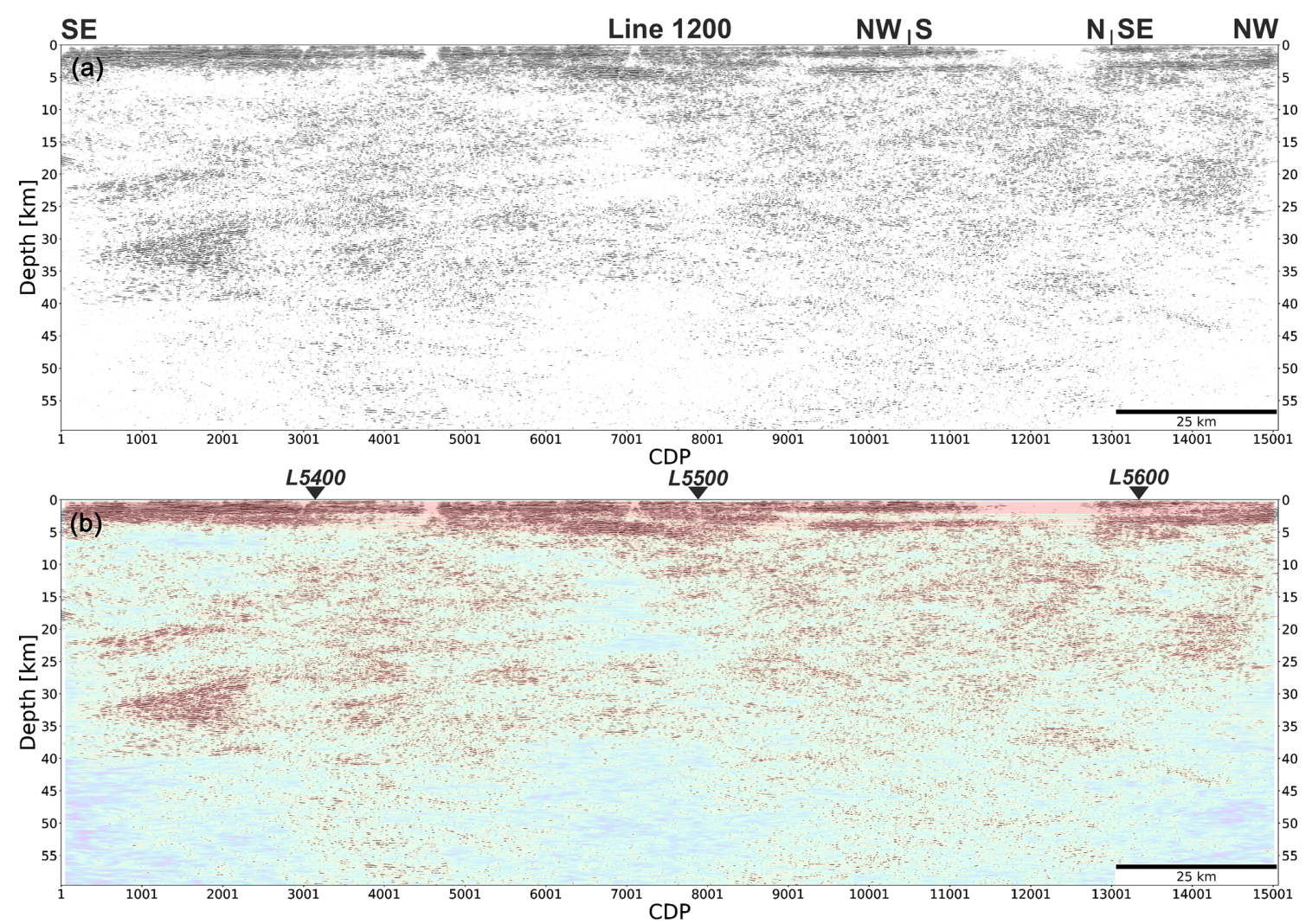

Figure 4. Final migrated depth-converted section along PolandSPAN ${ }^{\mathrm{TM}}$ profile 1200: (a) plot of positive amplitudes; (b) plot of positive amplitudes with amplitude envelope attribute in the background.

some distinct lower-crustal reflectivity patterns, with a common observation that the lower crust is reflective close to its top.

The black lines in Figs. 7-9 delineate representative reflection fabrics and shear zones, which we infer from the data. The main type of reflection corresponds to the gently dipping to subhorizontal structural layering, presumably representing Svekofennian orogenic fabric (labelled $S$ in Figs. 7-9). A number of low-angle discontinuities (15-20 $)$, inferred from the seismic reflections, branch off from the subhorizontal fabric and are followed by subparallel layering. These features, probably matching ductile thrust shear zones, are dipping towards NE and SE in the NE-SWand NW-SE-oriented sections, respectively (labelled $\mathrm{T}$ in Figs. 7-9). Collectively, their geometry is consistent with the previously postulated SW-to-W polarity of the Svekofennian orogen (e.g. Park, 1985; Gorbatschev and Bogdanova, 1993; Korja and Heikkinen, 1995, 2005; Nironen, 1997). The southwestward polarity of the orogen is also in accord with the NE-dipping upper mantle reflectors that may correspond to the preserved relics of a Paleoproterozoic subduction zone. In several places, at a lower-middle crust level, the subhorizontal reflectors or NE-dipping shear zones are truncated by a package of reflectors with an opposite dip, i.e. NW or SW directed, such as line 1200 between
CDP 1000 and 5000 (Fig. 7) and line 5400 between CDP 8000 and 12000 (Fig. 8). These SW-dipping events comprise straight reflections flanked by reflections bent into parallelism with the SW-inclined packages. Consequently, subhorizontal or NE-dipping sets of reflectors often acquire a sigmoidal shape with terminations aligned into the SWdipping events. The latter presumably correspond to extensional or transtensional shear zones of uniform geometry and kinematics throughout the studied sections. Both sets of structures identified in the seismic images jointly delineate a kilometre-scale $\mathrm{S}-\mathrm{C}^{\prime}$ fabric (Fig. 10) related to the SWdirected (in present-day coordinates) mid- and lower-crustal flow. The subhorizontal-to-NE-dipping, often sigmoidal reflectors represent first-order orogen-scale shear planes (S), whereas the SW-dipping events correspond to extensional shear zones $\left(\mathrm{C}^{\prime}\right)$ produced during orogen-scale non-coaxial flow (Fig. 10). A similar fabric was described by Torvela et al. (2013) for the FIRE profiles of onshore Finland. These authors link the structural pattern observed to the overall convergent tectonic setting of the accretionary Svecofennian orogeny (1.96-1.76 Ga; Korja and Heikkinen, 1995, 2005; Torvela et al., 2013). Following classical studies by Beaumont et al. (2001) and Vanderhaege and Teyssier (2001), Torvela et al. (2013) postulate syn-convergent flow of hot lower and middle crust comparable to that presently con- 

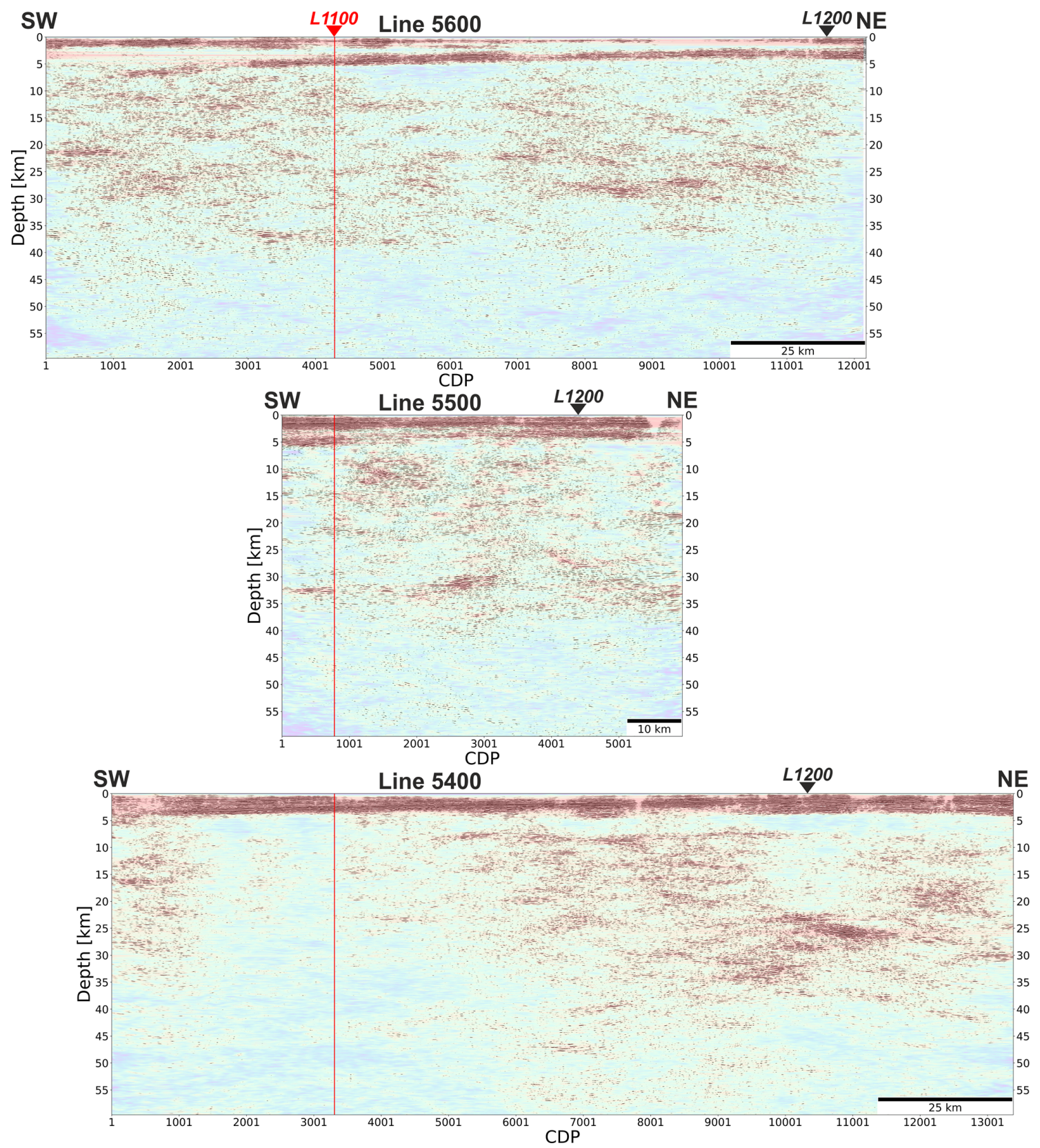

Figure 5. Final migrated depth-converted section along PolandSPAN ${ }^{\mathrm{TM}}$ profiles 5600, 5500, and 5400 (envelope and amplitude combined plot as in Fig. 4b). Profiles are centred at the intersection with line 1100 (vertical red line).

nected with the Tibetan Plateau (e.g. Beaumont et al., 2001, 2006; Lee and Whitehouse, 2007). According to these models, partial melting of thermally mature thickened orogenic crust and associated widespread migmatization results in the generation of low-viscosity crustal layer that may undergo extension in an overall convergent setting (e.g. Beaumont et al., 2001; Vanderhaege and Teyssier, 2001). Drill core data from the Paleoproterozoic basement of NE Poland actually confirm widespread migmatization and synorogenic magma- tism at the time of the Svekofennian orogeny (Krzemińska et al., 2017).

We favour the syn-convergent crustal flow explanation over late orogenic to post-orogenic extensional collapse (Korja and Heikkinen, 1995, 2005) due to the structural record from the AMCG igneous suite (Cymerman, 2004, 2014). Structural analysis of drill cores suggests localized compressive deformation of the Mesoproterozoic (1.54-1.45 Ga) AMCG intrusions (Cymerman, 2004, 2014), implying the cessation of orogenic-scale extension by the time of their 

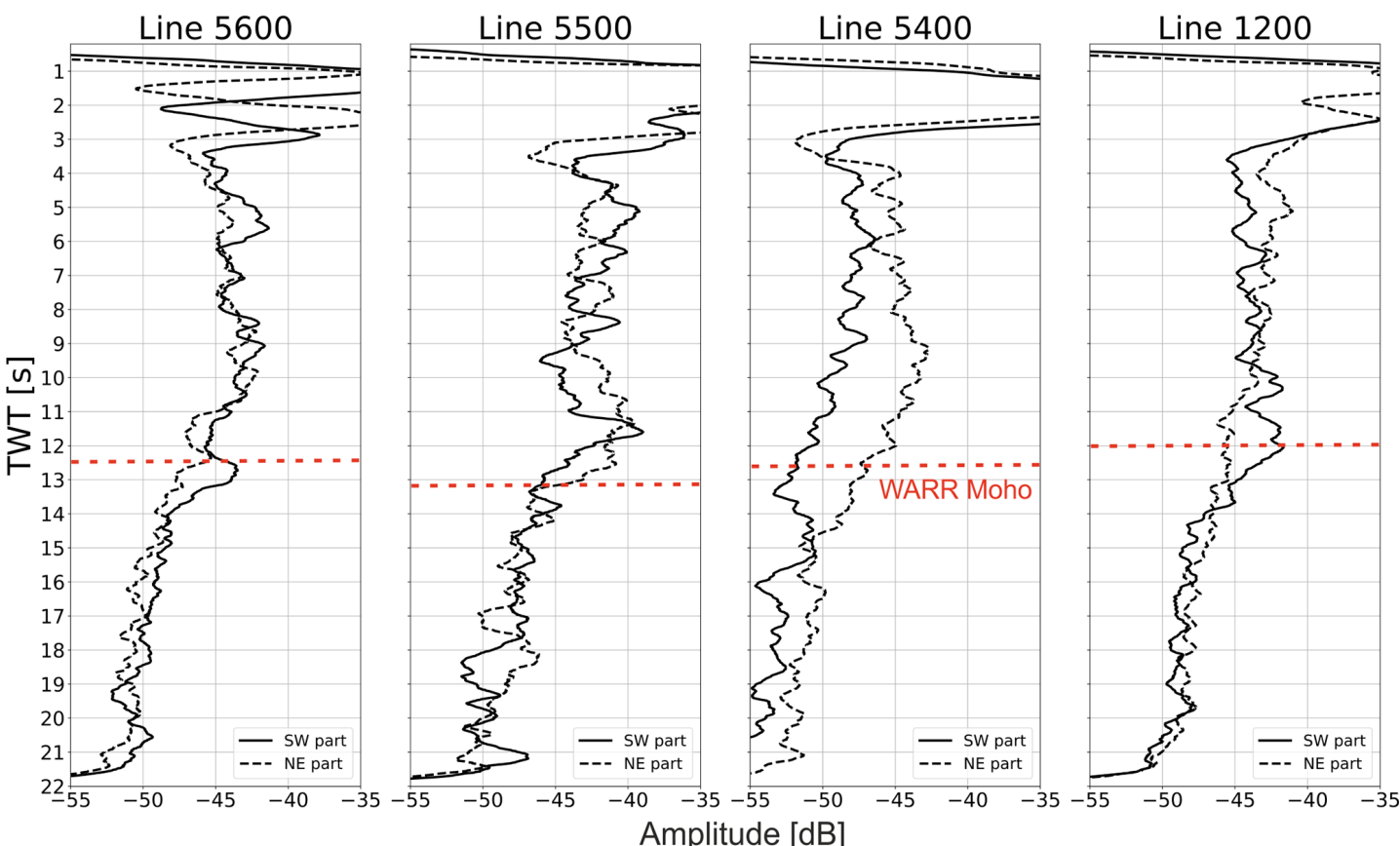

Figure 6. Amplitude decay curves extracted from the sections shown in Figs. 4 and 5. Red dashed line indicates average Moho depth inferred from WARR data.
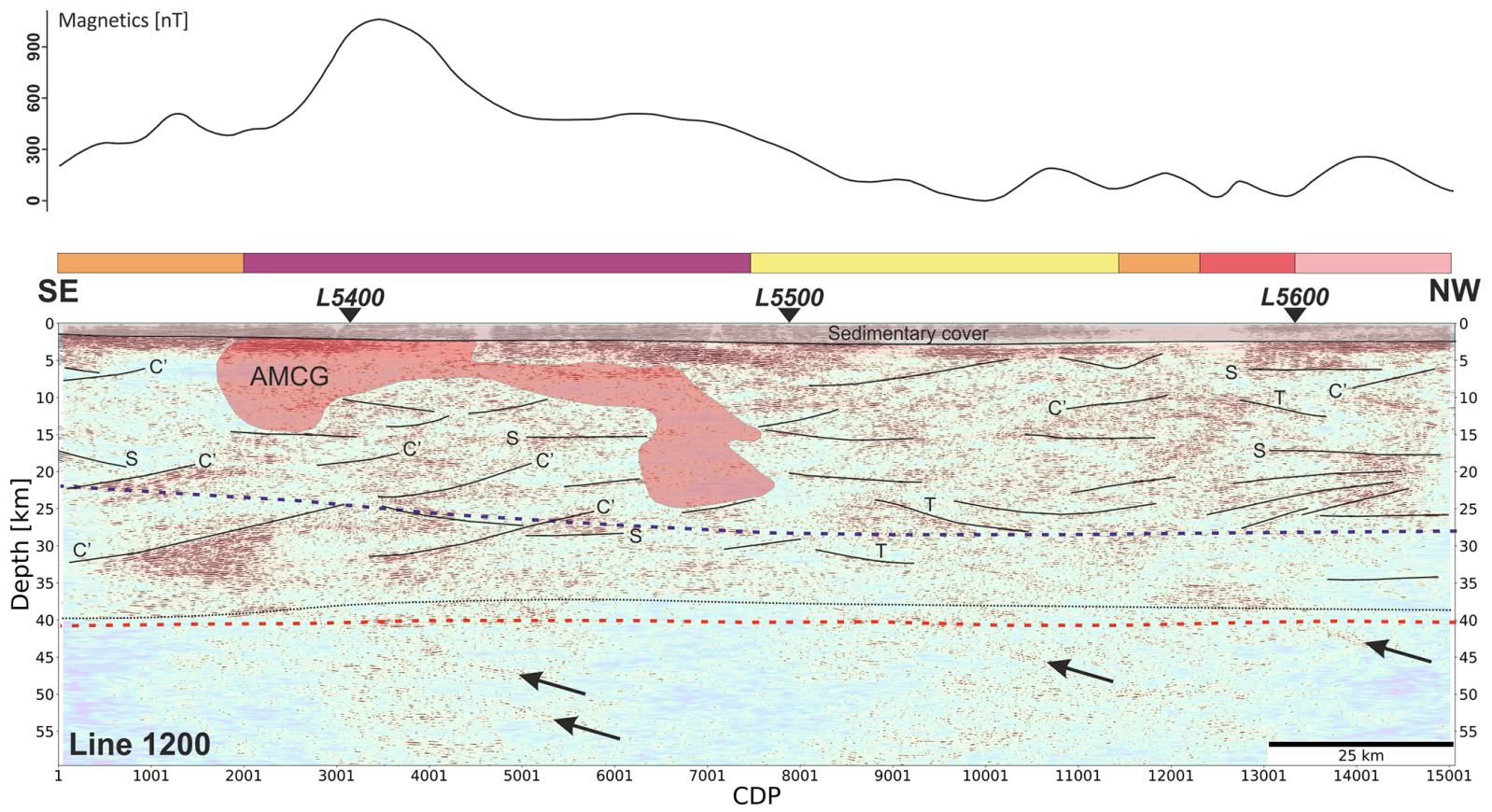

Figure 7. Final migrated depth-converted section along PolandSPAN ${ }^{\mathrm{TM}}$ profile 1200 with preliminary interpretation. Bars atop the section are colour-coded according to the crystalline basement lithologies following Krzemińska et al. (2017) (see Fig. 9 for a legend). The magnetic profile at the top is extracted from the magnetic anomaly map (Fig. 3). The dashed blue and red lines represent the top of the lower crust and Moho boundary, respectively, taken from the WARR compilation of Majdański (2012). The black dotted line is the interpreted Moho boundary from reflection data. Arrows point to the upper mantle reflectors (RUM). S - subhorizontal structural layering (Svekofennian orogenic fabric); $\mathrm{T}$ - ductile thrust shear zones; $\mathrm{C}^{\prime}$ - extensional shear zones. 


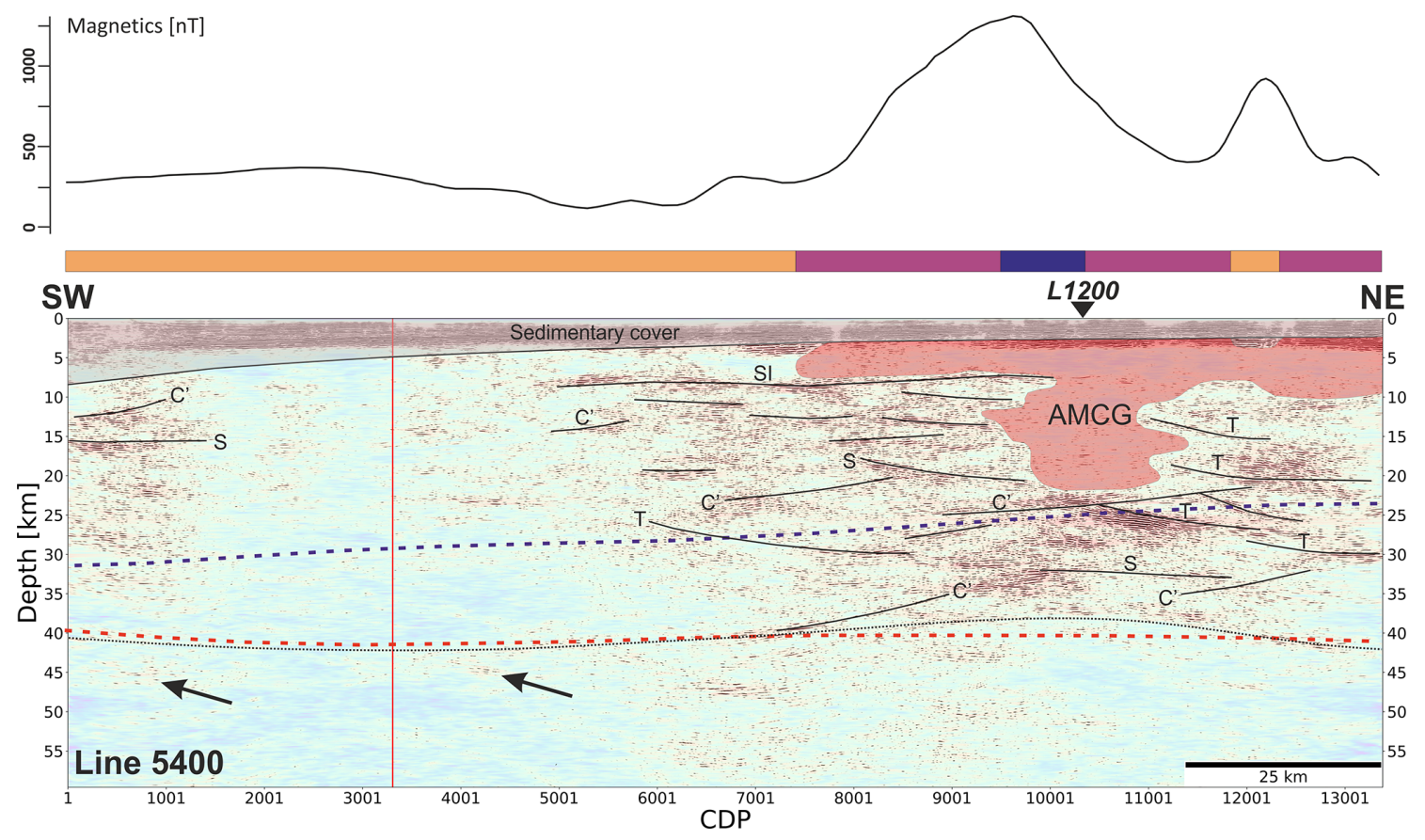

Figure 8. Final migrated depth-converted sections along PolandSPAN ${ }^{\mathrm{TM}}$ profile 5400 with its tentative interpretation. Bars atop the section are colour-coded according to the crystalline basement lithologies following Krzemińska et al. (2017) (see Fig. 9 for a legend). The magnetic profile at the top is extracted from the magnetic anomaly map (Fig. 3). S - subhorizontal structural layering (Svekofennian orogenic fabric); $\mathrm{T}$ - ductile thrust shear zones; $\mathrm{C}^{\prime}$ - extensional shear zones.

emplacement. The formation of the $\mathrm{S}-\mathrm{C}^{\prime}$ fabric, revealed by the seismic data, must have already been accomplished before the AMCG magmatism. Furthermore, seismic-scale deformational features are not imaged within the plutons (Figs. 7-9). However, some possible contacts of the AMCG bodies coincide with zones of increased crustal reflectivity, suggesting that reactivation of inherited shear zones may have provided conduits for the emplacement of magma. Consequently, we propose that delamination of over-thickened Svekofennian lithosphere may have accounted for underplating of gabbroic magma that fractionated into the AMCG plutons in NE Poland, following classical models of AMCG magmatism. See McLelland et al. (2010) for a review. The gabbroic parental magma yielded anorthositic derivatives subsequently ascending into the middle to upper crust together with granitoids derived by crustal anatexis (e.g. McLelland et al., 2010). Increased mantle reflectivity in the vicinity of the AMCG bodies may signify fragments of delaminated lower-crustal material. Sub-Moho reflectivity was also observed along the POLONAISE'97 P4 profile between the P3 and P5 profiles (Grad et al., 2002). The exact shape of a lower- to mid-crustal gabbroic body and its position with respect to the inferred subcrop of the MC AMCG rocks is likely controlled by the interplay between the magmatism and the structure developed during the Paleoproterozoic collisional and post-collisional deformations - a mechanism suggested for the Korosten Pluton by Bogdanova et al. (2004). Bright lower-crustal reflectors and their complex shape (with some truncations) observed in the vicinity of the AMCG suite along lines 1200 and 5400 seem to support such an idea. We have to point out that the interpreted shapes of the AMCG bodies in Figs. 7-9 are only tentative and rely on three pieces of evidence: (1) the presence of mostly transparent crust in seismic sections, (2) the occurrence of AMCG suite outcrops at the top of the basement (after Krzemińska et al., 2017), and (3) the concurrence of magnetic highs (Figs. 3, 7-9) due to the elevated magnetic susceptibility of AMCG rocks.

An interesting reflector (marked SI in Fig. 8) is observed along line 5400 for more than $60 \mathrm{~km}$ between CDPs 5000 and 10000 at a depth of $\sim 7-9 \mathrm{~km}$. It was also visible in the original ION Geophysical time-depth imaging, as well as in the industry seismic data from this area (Piotr Krzywiec, personal communication, 2019). It is offset with respect to the magnetic high crossed by line 5400 (Fig. 3). The S reflector can be tentatively linked with the AMCG intrusion, representing a sill (or top of the layered intrusion) fed by the mafic dykes as in the Shumlyanskyy et al. (2017) model for the Korosten Pluton in Ukraine. An alternative explanation invokes a much younger magmatic event. Since the lower Carboniferous syenite intrusion of the Olsztyn Massif (Fig. 2) is less than $100 \mathrm{~km}$ to the SE of line 5400, the SI reflector (and associated deeper subhorizontal reflectors) can be alternatively interpreted as intrusions of this age. Such an explanation for 

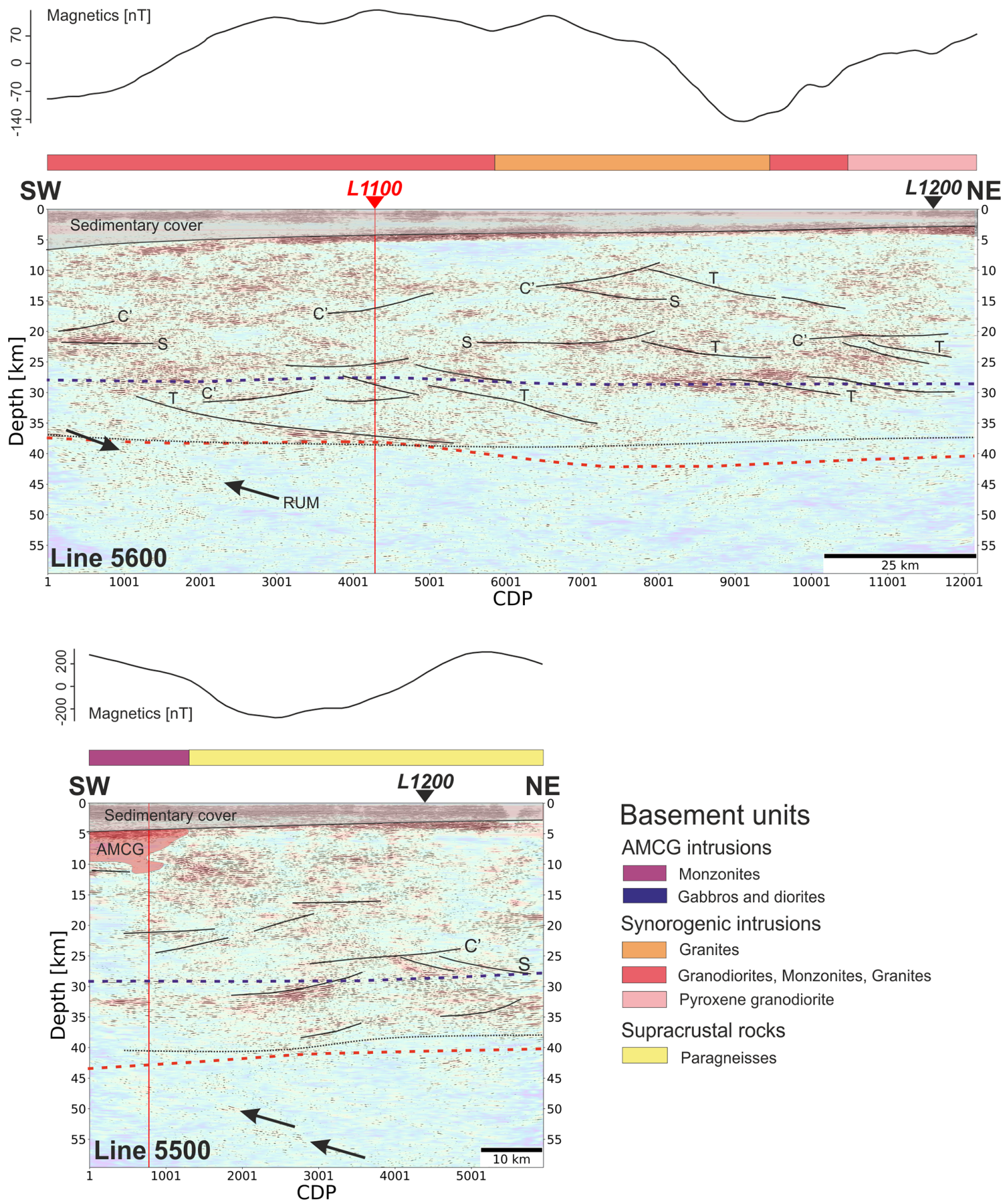

Basement units

AMCG intrusions

Monzonites

Gabbros and diorites

Synorogenic intrusions

$\square$ Granites

Granodiorites, Monzonites, Granites

Pyroxene granodiorite

Supracrustal rocks

Paragneisses

Figure 9. Final migrated depth-converted sections along PolandSPAN ${ }^{\mathrm{TM}}$ profiles 5500 and 5600 with their tentative interpretation. Bars atop the section are colour-coded according to the crystalline basement lithologies following Krzemińska et al. (2017) (see Fig. 9 for a legend). The magnetic profile at the top is extracted from the magnetic anomaly map (Fig. 3). S - subhorizontal structural layering (Svekofennian orogenic fabric); $\mathrm{T}$ - ductile thrust shear zones; $\mathrm{C}^{\prime}-$ extensional shear zones. 


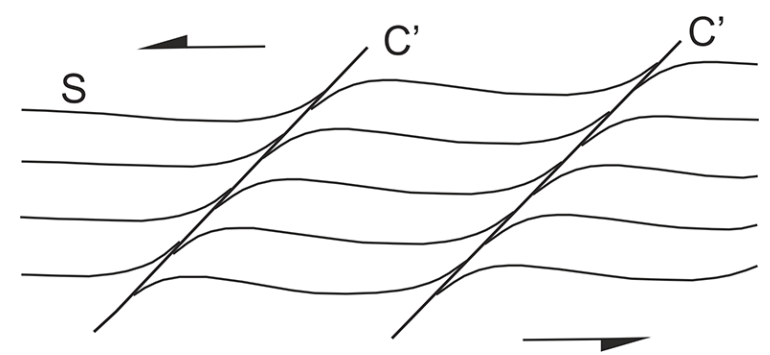

Figure 10. Schematic illustration of $S-C^{\prime}$ fabric. A set of extensional shear bands $\mathrm{C}^{\prime}$ forms oblique to the shear zone boundaries, dipping towards the shear direction in synthetic orientation. See also Fig. 16.22 in Fossen (2016).

the SI reflector origin is also supported by the fact that the lower Carboniferous sills were drilled offshore of Lithuania (Motuza et al., 2015).

The BABEL seismic profiles in the Baltic Sea imaged several dipping sub-Moho reflectors projecting into the Fennoscandian mantle (Abramovitz et al., 1997; BABEL Working Group, 1993; Balling, 2000; Korja and Heikkinen, 2005). The pronounced dipping mantle reflector observed $\mathrm{NE}$ of the Bornholm area along the BABEL A line (from 40 to $65 \mathrm{~km}$ of depth) was interpreted by Balling (2000) as a relic of paleosubduction occurring at $\sim 1.8-1.7 \mathrm{Ga}$. The same reflections projecting into the mantle were also imaged by the DEKORP-PQ profiles parallel to the BABEL A profile close to Bornholm, and they were also attributed to the Proterozoic terrane accretion (Krawczyk et al., 2002; Meissner and Krawczyk, 1999). Projecting the BABEL A and PQ mantle reflectors onto line 5600 suggests that we may observe the same feature at the SW end of this profile. Krawczyk et al. (2002) concluded that the Baltica crust was not mechanically involved in the Caledonian collision. This view can be supported by the recent study by Mazur et al. (2016b), who suggested that the Caledonian Deformation Front (CDF) is a thin-skinned feature. Therefore, we do not link the observed reflectivity patterns (including mantle reflectors) with Caledonian deformation but consider them to represent a Proterozoic accretion signature.

\section{Conclusions}

Reprocessing of $\sim 950 \mathrm{~km}$ of the regional seismic profiles from the PolandSPAN ${ }^{\mathrm{TM}}$ project provided for the first time a detailed picture of the EEC (Fennoscandian) crust in NE Poland. It revealed reflectivity patterns that we primarily associate with Paleoproterozoic crustal formation during the Svekofennian (Svekobaltic) orogeny and that are similar to those observed along the BABEL and FIRE profiles in the Baltic Sea and onshore Finland, respectively (Korja and Heikkinen, 2005; Torvela et al., 2013). We suggest that a seismic-scale $\mathrm{S}-\mathrm{C}^{\prime}$ fabric of the Paleoproterozoic crust was shaped by mid- to lower-crustal flow in a convergent setting during the Svekofennian orogeny. We propose that delamination of the thickened Svecofennian lithosphere and resulting asthenospheric ascent, partial melting of the lithospheric mantle, and ponding of gabbroic melt at the crust-mantle interface (McLelland et al., 2010) can be reconciled with the observed crustal fabric and explain the emplacement of the Mesoproterozoic AMCG suites in NE Poland. We also found sub-Moho dipping mantle reflectivity, which we tentatively explain as a signature of paleosubduction occurring prior to the Svekofennian orogeny. Later tectonic phases (e.g. Ediacaran rifting, Caledonian orogeny) did not leave a clear signature in the deeper crust; however, some of the subhorizontal reflectors below the basement may be linked to a lower Carboniferous magmatism.

Data availability. Data used in this research are not publicly available and were provided based on the agreement between Institute of Geophysics, Polish Academy of Sciences and ION Geophysical.

Author contributions. Conceptualization was carried out by MMal. $\mathrm{MM}$ and MMal were responsible for methodology, MM was responsible for software, and MM and MMal were responsible for validation. MM, MMal, and SM carried out the normal analysis; $\mathrm{MM}$ and MMal conducted the investigation, and MMal secured resources. MM and MMal were responsible for data curation. MM, MMal, and SM participated in writing, original draft preparation, review and editing, and visualization. MMal was responsible for supervision, project administration, and funding acquisition.

Competing interests. The authors declare that they have no conflict of interest.

Special issue statement. This article is part of the special issue "Advances in seismic imaging across the scales". It is a result of the 14th International Symposium on Deep Seismic Profiling of the Continents and their Margins, Cracow, Poland, 17-22 June 2018.

Acknowledgements. We are grateful to Andrew Calvert for sharing his coherency filtration and segment migration codes with us. We are indebted to ION Geophysical for permission to use and show PolandSPAN $^{\mathrm{TM}}$ data. Processing was done using GlobeClaritas ${ }^{\mathrm{TM}}$ software under the licence from GNS Science, New Zealand. Comments from the two anonymous reviewers are greatly appreciated. Comments by Svetlana Bogdanova on an earlier version of the paper helped us to clarify some aspects of the geological interpretation.

Financial support. This research has been supported by the National Science Centre (grant no. UMO-2015/19/B/ST10/01612). 
Review statement. This paper was edited by Ramon Carbonell and reviewed by two anonymous referees.

\section{References}

Abramovitz, T., Berthelsen, A., and Thybo, H.: Proterozoic sutures and terranes in the southeastern Baltic Shield interpreted from BABEL deep seismic data, Tectonophysics, 270, 259-277, https://doi.org/10.1016/S0040-1951(96)00213-2, 1997.

BABEL Working Group: Deep Seismic Reflection/Refraction Interpretation of Crustal Structure Along Babel Profiles A and B In the Southern Baltic Sea: Babel Working Group, Geophys. J. Int., 112, 325-343, https://doi.org/10.1111/j.1365246X.1993.tb01173.x, 1993.

Balling, N.: Deep seismic reflection evidence for ancient subduction and collision zones within the continental lithosphere of Northwestern Europe, Tectonophysics, 329, 269-300, https://doi.org/10.1016/S0040-1951(00)00199-2, 2000.

Barnes, A. E.: Moho reflectivity and seismic signal penetration, Tectonophysics, 232, 299-307, https://doi.org/10.1016/00401951(94)90091-4, 1994.

Beaumont, C., Jamieson, R. A., Nguyen, M. H., and Lee, B.: Himalayan tectonics explained by extrusion of a low-viscosity crustal channel coupled to focused surface denudation, Nature, 414, 738-742, 2001.

Beaumont, C., Nguyen, M. H., Jamieson, R. A., and Ellis, S.: Crustal flow modes in large hot orogens, Geological Society, London, Special Publications, 268, 91-145, 2006.

Bogdanova, S., Gorbatschev, R., Skridlaite, G., Soesoo, A., Taran, L., and Kurlovich, D.: Trans-Baltic Palaeoproterozoic correlations towards the reconstruction of supercontinent Columbia/Nuna, Precambrian Res., 259, 5-33, https://doi.org/10.1016/J.PRECAMRES.2014.11.023, 2015.

Bogdanova, S. V., Pashkevich, I. K., Buryanov, V. B., Makarenko, I. B., Orlyuk, M. I., Skobelev, V. M., Starostenko, V. I., and Legostaeva, O. V.: The 1.80-1.74-Ga gabbro-anorthositerapakivi Korosten Pluton in the Ukrainian Shield: a 3-D geophysical reconstruction of deep structure, Tectonophysics, 381, 5-27, https://doi.org/10.1016/J.TECTO.2003.10.023, 2004.

Bogdanova, S. V., Bingen, B., Gorbatschev, R., Kheraskova, T. N., Kozlov, V. I., Puchkov, V. N., and Volozh, Y. A.: The East European Craton (Baltica) before and during the assembly of Rodinia, Precambrian Res., 160, 23-45, https://doi.org/10.1016/j.precamres.2007.04.024, 2008.

Calvert, A. J.: A method for avoiding artifacts in the migration of deep seismic reflection data, Tectonophysics, 388, 201-212, https://doi.org/10.1016/J.TECTO.2004.07.026, 2004.

Christensen, N. I. and Mooney, W. D.: Seismic velocity structure and composition of the continental crust: a global view, J. Geophys. Res., 100, 9761-9788, https://doi.org/10.1029/95JB00259, 1995.

Cymerman, Z.: Precambrian of the Polish part of the East European Platform: tectonics and crustal development, Prace Państwowego Instytutu Geologicznego, CLXXX, 1-129, 2004 (in Polish, English summary).

Cymerman, Z.: Structural and kinematic analysis and the Mesoproterozoic tectonic evolution of the Suwałki basic massif and its surroundings, NE Poland, Prace Państwowego Instytutu Geologicznego, 201, 1-167, 2014 (in Polish, English summary).

Czuba, W., Grad, M., Luosto, U., Motuza, G., Nasedkin, V., Guterch, A., Środa, P., Keller, G. R., Thybo, H., Türa, T., Yliniemi, J., Lund, C. E., Jacyna, J., Korabliova, L., and Nasedkin, V.: Upper crustal seismic structure of the Mazury complex and Mazowsze massif within East Europe Craton in NE Poland, Tectonophysics, 360, 115-128, https://doi.org/10.1016/S00401951(02)00352-9, 2002.

Dadlez, R., Kowalczewski, Z., and Znosko, J.: Some key problems of the pre-Permian tectonics of Poland, Geol. Q., 38, 169-190, 1994.

Dörr, W., Belka, Z., Marheine, D., Schastok, J., Valverde-Vaquero, P., and Wiszniewska, J.: U-Pb and Ar-Ar geochronology of anorogenic granite magmatism of the Mazury complex, NE Poland, Precambrian Res., 119, 101-120, https://doi.org/10.1016/S0301-9268(02)00119-5, 2002.

Dziewinska, L. and Tarkowski, R.: Geophysical study of deep basement structure of NW Poland using effective reflection coefficients, C. R. Geosci., 348, 587-597, https://doi.org/10.1016/J.CRTE.2016.06.003, 2016.

Fossen, H.: Structural Geology, Cambridge University Press, 2016.

Gorbatschev, R. and Bogdanova, S.: Frontiers in the Baltic Shield, Precambrian Res., 64, 3-21, https://doi.org/10.1016/03019268(93)90066-B, 1993.

Grad, M., Keller, Thybo, H., and Guterch, A.: Lower lithospheric structure beneath the Trans-European Suture Zone from POLONAISE'97 seismic profiles, Tectonophysics, 360, 153168, https://doi.org/10.1016/S0040-1951(02)00350-5, 2002.

Grad, M., Jensen, S. L., Keller, G. R., Guterch, A., Thybo, H., Janik, T., Tiira, T., Yliniemi, J., Luosto, U., Motuza, G., Nasedkin, V., Czuba, W., Gaczyński, E., Środa, P., Miller, K. C., WildePiórko, M., Komminaho, K., Jacyna, J., and Korabliova, L.: Crustal structure of the Trans-European suture zone region along POLONAISE'97 seismic profile P4, J. Geophys. Res., 108, 2541, https://doi.org/10.1029/2003JB002426, 2003.

Grad, M., Janik, T., Guterch, A., Środa, P., and Czuba, W.: Lithospheric structure of the western part of the East European Craton investigated by deep seismic profiles, Geol. Q., 50, 9-22, 2010.

Grad, M., Polkowski, M., and Ostaficzuk, S. R.: Highresolution 3D seismic model of the crustal and uppermost mantle structure in Poland, Tectonophysics, 666, 188-210, https://doi.org/10.1016/J.TECTO.2015.10.022, 2016.

Guterch, A., Grad, M., Janik, T., Materzok, R., Luosto, U., Yliniemi, J., Lück, E., Schulze, A., and Förste, K.: Crustal structure of the transition zone between Precambrian and Variscan Europe from new seismic data along LT-7 profile (NW Poland and eastern Germany), C. R. Acad. Sci. Paris, 319, 1489-1496, 1994.

Janik, T., Yliniemi, J., Grad, M., Thybo, H., Tiira, T., Gaczyński, E., Guterch, A., Keller, G. R., and Komminaho, K.: Crustal structure across the TESZ along Polonaise'97 seismic profile P2 NW Poland, Tectonophysics, 360, 129-152, https://doi.org/10.1016/S0040-1951(02)00353-0, 2002.

Johansson, A.: Baltica, Amazonia and the SAMBA connection - 1000 million years of neighbourhood during the Proterozoic?, Precambrian Res., 17, 221-234, https://doi.org/10.1016/J.PRECAMRES.2009.09.011, 2009.

Korja, A. and Heikkinen, P.: The accretionary Svecofennian orogen - insight from the BABEL profiles, Precambrian Res., 136, 
241-268, https://doi.org/10.1016/J.PRECAMRES.2004.10.007, 2005.

Korja, A. and Heikkinen, P. J.: Proterozoic extensional tectonics of the central Fennoscandian Shield: Results from the Baltic and Bothnian Echoes from the Lithosphere experiment, Tectonics, 14, 504-517, https://doi.org/10.1029/94TC02905, 1995.

Krawczyk, C., Eilts, F., Lassen, A., and Thybo, H.: Seismic evidence of Caledonian deformed crust and uppermost mantle structures in the northern part of the Trans-European Suture Zone, SW Baltic Sea, Tectonophysics, 360, 215-244, https://doi.org/10.1016/S0040-1951(02)00355-4, 2002.

Krzemińska, E., Krzemiński, L., Petecki, Z., Wiszniewska, J., Salwa, S., Żaba, J., Gaidzik, K., Williams, I.S., Rosowiecka, O, Taran, L., Johansson, Å., Pécskay, Z., Demaiffe, D., Grabowski, J., and Zieliński, G.: Geological Map of Crystalline Basement in the Polish part of the East European Platform 1:1000000, Państwowy Instytut Geologiczny, Warszawa, 2017.

Krzywiec, P., Lis, P., Buffenmyer, V., Malinowski, M., and Lewandowski, M.: Regional Geologic Characterization of the Polish Lower Paleozoic Unconventional Play Using an Integrated Seismic and Well Data Approach, in Unconventional Resources Technology Conference, Denver, Colorado, 12-14 August 2013, Society of Exploration Geophysicists, American Association of Petroleum Geologists, Society of Petroleum Engineers, 183-187, 2013.

Krzywiec, P., Mazur, S., Gągała, Ł., Kufrasa, M., Lewandowski, M. and Malinowski, and MichałBuffenmyer, V.: Late Carboniferous thin-skinned compressional deformation above the SW edge of the East European craton as revealed by seismic reflection and potential field data - Correlations with the Variscides and the Appalachians, in GSA Memoirs: Linkages and Feedbacks in Orogenic Systems, Geological Society of America, 213, 353-372, 2017a.

Krzywiec, P., Gągała, Mazur, S., Słonka, Kufrasa, M., Malinowski, M., Pietsch, K., and Golonka, J.: Variscan deformation along the Teisseyre-Tornquist Zone in SE Poland: Thick-skinned structural inheritance or thin-skinned thrusting?, Tectonophysics, 718, 8391, https://doi.org/10.1016/j.tecto.2017.06.008, 2017b.

Kukkonen, I. T. and Lahtinen, R.: Finnish reflection experiment FIRE 2001-2005, Geological Survey of Finland, 2006.

Lahtinen, R., Korja, A., Nironen, M., and Heikkinen, P.: Palaeoproterozoic accretionary processes in Fennoscandia, Geol. Soc. London Spec. Publ., 318, 237-256, https://doi.org/10.1144/SP318.8, 2009.

Lee, J. and Whitehouse, M. J.: Onset of mid-crustal extensional flow in southern Tibet: Evidence from U/Pb zircon ages, Geology, 35, 45-48, 2007.

Majdański, M.: The structure of the crust in TESZ area by kriging interpolation, Acta Geophys., 60, 59-75, https://doi.org/10.2478/s11600-011-0058-5, 2012.

Malinowski, M.: Deep reflection seismic imaging in SE Poland using extended correlation method applied to PolandSPAN ${ }^{\mathrm{TM}}$ data, Tectonophysics, 689, 107-114, https://doi.org/10.1016/j.tecto.2016.01.007, 2016.

Malinowski, M. and Brettwood, P.: Using Extended Correlation Method in Regional Reflection Surveys - A Case Study from Poland, in 75th EAGE Conference \& Exhibition incorporating SPE EUROPEC 2013 London, UK, 10-13 June 2013.
Malinowski, M., Guterch, A., Narkiewicz, M., Probulski, J., Maksym, A., Majdański, M., Środa, P., Czuba, W., Gaczyński, E., Grad, M., Janik, T., Jankowski, L., and Adamczyk, A.: Deep seismic reflection profile in Central Europe reveals complex pattern of Paleozoic and Alpine accretion at the East European Craton margin, Geophys. Res. Lett., 40, 3841-3846, https://doi.org/10.1002/grl.50746, 2013.

Malinowski, M., Guterch, A., Narkiewicz, M., Petecki, Z., Janik, T., Środa, P., Maksym, A., Probulski, J., Grad, M., Czuba, W., Gaczyński, E., Majdański, M., and Jankowski, L.: Geophysical constraints on the crustal structure of the East European Platform margin and its foreland based on the POLCRUST-01 deep reflection seismic profile, Tectonophysics, 653, 109-126, https://doi.org/10.1016/j.tecto.2015.03.029, 2015.

Mazur, S., Mikolajczak, M., Krzywiec, P., Malinowski, M., Buffenmyer, V., and Lewandowski, M.: Is the Teisseyre-Tornquist Zone an ancient plate boundary of Baltica?, Tectonics, 34, 2465-2477, https://doi.org/10.1002/2015TC003934, 2015.

Mazur, S., Mikolajczak, M., Krzywiec, P., Malinowski, M., Lewandowski, M., and Buffenmyer, V.: Pomeranian Caledonides, NW Poland - A collisional suture or thinskinned fold-and-thrust belt?, Tectonophysics, 692, 29-43, https://doi.org/10.1016/j.tecto.2016.06.017, 2016a.

Mazur, S., Mikolajczak, M., Krzywiec, P., Malinowski, M., Buffenmyer, V., and Lewandowski, M.: Reply to Comment by M. Narkiewicz and Z. Petecki on "Is the Teisseyre-Tornquist Zone an ancient plate boundary of Baltica?", Tectonics, 35, 16001607, https://doi.org/10.1002/2016TC004162, 2016b.

McLelland, J. M., Selleck, B. W., Hamilton, M. A., and Bickford, M. E.: Late-to post-tectonic setting of some major Proterozoic anorthosite-mangerite-charnockitegranite (AMCG) suites, Can. Mineral., 48, 729-750, https://doi.org/10.3749/canmin.48.4.729, 2010.

Meissner, R. and Krawczyk, C. H.: Caledonian and Proterozoic terrane accretion in the southwest Baltic Sea, Tectonophysics, 314, 255-267, https://doi.org/10.1016/S0040-1951(99)00247-4, 1999.

Mezyk, M. and Malinowski, M.: Deep Neural Network and Multipattern Based Algorithm for Picking First-arrival Traveltimes, in 80th EAGE Conference and Exhibition, Copenhagen, 2018.

Motuza, G., Šliaupa, S., and Timmerman, M. J.: Geochemistry and ${ }^{40} \mathrm{Ar} /{ }^{39} \mathrm{Ar}$ age of Early Carboniferous dolerite sills in the southern Baltic Sea, Est. J. Earth Sci., 64, 233, https://doi.org/10.3176/earth.2015.30, 2015.

Nironen, M.: The Svecofennian Orogen: a tectonic model, Precambrian Res., 86, 21-44, 1997.

Okaya, D. A. and Jarchow, C. M.: Extraction of deep crustal reflections from shallow Vibroseis data using extended correlation, Geophysics, 54, 555-562, https://doi.org/10.1190/1.1442682, 1989.

Park, A. F.: Accretion tectonism in the Proterozoic Svecokarelides of the Baltic Shield, Geology, 13, 725-729, 1985.

Shumlyanskyy, L., Hawkesworth, C., Billström, K., Bogdanova, S., Mytrokhyn, O., Romer, R., Dhuime, B., Claesson, S., Ernst, R., Whitehouse, M., and Bilan, O.: The origin of the Palaeoproterozoic AMCG complexes in the Ukrainian shield: New U-Pb ages and Hf isotopes in zircon, Precambrian Res., 292, 216-239, https://doi.org/10.1016/J.PRECAMRES.2017.02.009, 2017. 
Skridlaite, G., Wiszniewska, J., and Duchesne, J.-C.: Ferro-potassic A-type granites and related rocks in NE Poland and S Lithuania: west of the East European Craton, Precambrian Res., 124, 305326, https://doi.org/10.1016/S0301-9268(03)00090-1, 2003.

Środa, P., Czuba, W., Guterch, A., Środa, P., Grad, M., Thybo, H., Keller, G. R., Miller, K. C., Tiira, T., Luosto, U., Yliniemi, J., Motuza, G., and Nasedkin, V.: P- and S-wave velocity model of the southwestern margin of the Precambrian East European Craton; POLONAISE'97, profile P3, Tectonophysics, 314, 175-192, 1999.
Torvela, T., Moreau, J., Butler, R.W., Korja, A., and Heikkinen, P.: The mode of deformation in the orogenic mid-crust revealed by seismic attribute analysis, Geochem. Geophy. Geosy., 14, 10691086, 2013.

Vanderhaege, O. and Teyssier, C.: Partial melting and flow of orogens, Tectonophysics, 342, 451-472, 2001.

Ziolkowski, A.: Review of vibroseis data acquisition and processing for better amplitudes: adjusting the sweep and deconvolving for the time-derivative of the true groundforce, Geophys. Prospect., 58, 41-54, https://doi.org/10.1111/j.13652478.2009.00841.x, 2010. 